\title{
MEMBANGUN TEOLOGI TUBUH DARI BAWAH BELAJAR DARI PENGALAMAN OLAH TUBUH TARI LENGGER
}

\author{
Robertus Suraji \\ Dosen Religi dan Budaya, Ilmu Komunikasi Fakultas Humaniora President University \\ Jl. Ki Hajar Dewantara, Cikarang Baru, Bekasi Barat, Jawa Barat. \\ E-mail: surajprpwt@yahoo.com
}

\begin{abstract}
The word theology comes from the Greek word theos which means God, and logos which means words. Thus theology means words or knowledge about God. The body can say or show or remind something about God as the ruler of human body and life. Reflection on body can bring people to the knowledge of God. The experience of lengger dancers working on the body makes them believe in the existence of God as the origin of his body, even though they did not dare to expressly mention the name of Allah behind all of these experiences. Body work experience gives them confidence that there is something behind this visible physical body. However, the human body is not only owned by a person, but has become a sign system of community culture. The body no longer only has the meaning of itself, but also must obey the general norms that apply in the society where a person lives. The meaning of the lengger dancer's body is very dependent on the interpretation of the surrounding community, the majority of whom are Muslim. While Islam teaches that the body, especially the female body, must be protected because it has the potential to bring sin. However, the community's interpretation of the body is not monolithic. The situation and culture in which they live determines the interpretation of how to treat the female body. This is where there is often a value tension between Islamic teachings and traditional values.
\end{abstract}

Keywords:

Body, lengger, theology

\begin{abstract}
Abstrak
Kata teologi berasal dari kata Yunani theos yang berarti Tuhan, dan logos yang berarti kata-kata. Jadi teologi berarti kata-kata atau pengetahuan tentang Tuhan. Tubuh dapat mengatakan atau menunjukkan atau mengingatkan sesuatu tentang Tuhan sebagai penguasa tubuh manusia dan kehidupan. Refleksi pada tubuh dapat membawa orang kepada pengetahuan tentang Tuhan. Pengalaman para penari lengger yang bekerja di tubuh membuat mereka percaya akan keberadaan Tuhan sebagai asal-usul tubuhnya, meskipun mereka tidak berani secara tegas menyebutkan nama Allah di balik semua pengalaman ini. Pengalaman kerja tubuh memberi mereka keyakinan bahwa ada sesuatu di balik tubuh fisik yang terlihat ini. Namun, tubuh manusia tidak hanya dimiliki oleh seseorang, tetapi telah menjadi tanda sistem budaya masyarakat. Tubuh tidak lagi hanya memiliki makna itu sendiri, tetapi juga harus mematuhi normanorma umum yang berlaku dalam masyarakat di mana seseorang hidup. Makna tubuh penari lengger sangat bergantung pada interpretasi masyarakat sekitar, yang mayoritas beragama Islam. Sementara Islam mengajarkan bahwa tubuh, terutama tubuh perempuan, harus dilindungi karena berpotensi membawa dosa. Namun, penafsiran masyarakat terhadap tubuh tidak monolitik. Situasi dan budaya di mana mereka tinggal menentukan interpretasi bagaimana memperlakukan tubuh wanita. Di sinilah sering ada ketegangan nilai antara ajaran Islam dan nilai-nilai tradisional.
\end{abstract}

Keywords:

Badan, lengger, teologi

\section{A. PENDAHULUAN}

Tubuh manusia bukan hanya milik seorang secara pribadi, tetapi telah menjadi sistem tanda dari budaya masyarakat. Tubuh tidak lagi hanya mempunyai arti dari dirinya sendiri, tetapi juga harus menuruti norma umum yang berlaku di masyarakat di mana seseorang hidup. Di satu sisi tubuh telah menjadi komoditas yang harus dijaga dan dipersiapkan demi "nilai jual" tertentu, di sisi lain tubuh juga menjadi fondasi untuk 
memperjuangkan kepentingan kelompok atau mengingatkan publik pada kekayaan peradaban manusia. Sejak ribuan tahun yang lalu tubuh telah menjadi kenyataan yang paradoksal, dan bagaimana tubuh harus diperlakukan telah menjadi perdebatan dalam sejarah (Synnott, 1993: 8-9). Bahkan dalam agama-agama besar, khususnya Kristen dan Islam bagaimana memperlakukan tubuh telah menjadi masalah tersendiri.

Di Indonesia akhir-akhir ini kesusilaan yang berkaitan dengan tubuh seakan memuncaki hirarki moralitas publik. Tubuh kerap lebih menjadi tertuduh sebagai penyebab rusaknya moral anak bangsa. Suatu seni yang mengekplorasi tubuh kerap kali harus berhadapan dengan penilaian moral. Tari lengger Banyumasan, misalnya, termasuk kesenian rakyat yang merasakan dampak dari hal tersebut. Sebagai suatu agriculture performance, tari lengger sangat erat hubungannya dengan gerakan tubuh sebagai simbol dari kesuburan. Hal ini menjadikan tari lengger kerap dituduh mengekploitasi erotisme. Sebagai akibatnya, kesenian yang tumbuh di daerah pertanian ini mengalami kesulitan untuk dapat berkembang dan mengadakan pementasan karena harus menghadapi penilain moral keagamaan dari masyarakat yang mayoritas adalah pemeluk agama Islam.

\section{B. MASALAH}

Islam adalah pihak yang dominan dalam pembentukan nilai di masyarakat Banyumas. Dengan demikian konsepsi mengenai tubuh di masyarakat Banyumas adalah tubuh yang sesuai dengan nilai-nilai Islam. Di tengah dominasi Islam tersebut keberadaan tari lengger yang terkenal dengan eksploitasi seksualitas menjadi suatu anomaly dan menimbulkan tegangan. Di satu sisi kendati tari lengger menonjolkan erotisme, tetapi tari ini adalah tari tradional yang menjadi ciri khas masyarakat Banyumas, di sisi lain ekplorasi tubuh oleh tari lengger tidak mencerminkan nilai-nilai Islam. Bahwa tari lengger masih tetap eksis dan diterima oleh masyarakat adalah sesuatu yang perlu diteliti. Oleh karena itu, pertanyaannya adalah mengapa tari lengger yang cenderung mengekploitasi seksualitas ini diterima oleh warga masyarakat desa Gerduren yang mayoritas beragama Islam? Dari perspektif studi agama dan budaya, tafsir seperti apa yang dapat dibangun atas seni berolah tubuh seperti yang diperagakan oleh tari lengger?

\section{HASIL DAN PEMBAHASAN}

\section{Tari Lengger Banyumasan}

Menurut sejarahnya tari lengger diperkirakan berasal dari semacam ungkapan rasa terimakasih kepada dewa-dewi kesuburan. Menurut Tohari (1995), budayawan yang mengarang novel Ronggeng Dukuh Paruk, pada jaman dahulu tari lengger dimainkan pada masa sesudah panen sebagai ungkapan syukur masyarakat terhadap para Dewa yang telah memberikan rejeki (Suraji, 2004: 28). Masa sesudah panen adalah masa untuk bersukaria bagi para petani. Pada saat itu para penari ledhek (tarian sejenis lengger) sibuk melayani pesanan untuk menari (Koentjaraningrat, 1994: 211-212). Bukan hanya sebagai ungkapan syukur sesudah panen saja, tetapi lengger memang mempunyai hubungan yang erat dengan permohonan kesejahteraan bagi suatu kelompok masyarakat petani melalui berbagai upacara ritual seperti bersih desa, baritan, marungan, dan upacara kaulan. Di sini fungsi utama dari tari lengger adalah sebagai komponen dalam agricultural ceremonie semacam upacara kesuburan (Sunaryadi, 2000: 35,42). Dengan demikian dapat dikatakan bahwa tari lengger pada awalnya adalah sebuah tarian religius, atau dapat 
disebut sebagai tarian keagamaan lokal. Sebagai tarian keagamaan, lengger pada saat itu belum menjadi seni pertunjukan seperti sekarang ini dan oleh karenanya juga tidak memasang tarif ketika mereka mengadakan pentas.

Ada pendapat yang menyatakan bahwa kemungkinan tari lengger sebagai tarian berasal dari India, atau merupakan pengaruh agama Hindu yang masih tersisa pada kebudayaan Jawa sampai sekarang ini (Suraji, 2004: 28). Menurut pendapat tersebut ronggeng (nama lain dari lengger) merupakan hasil pengaruh dari kegiatan ritus keagamaan di India Selatan, yaitu pesta seks di pusat keagamaan (kuil) sebagai sarana pemujaan terhadap Dewi Durga. Dalam Hinduisme di India pada masa lampau ada golongan (sekte) mistikus, yaitu golongan Ciwa Cakta Tantrayana, yang di dalam cita-citanya mengejar moksa dengan jalan sesingkatsingkatnya, antara lain dengan persetubuhan (maithuna). Menurut ajaran sekte ini, tidak ada sesuatupun yang kotor bagi manusia yang bersih. Lima larangan yaitu mamsa (daging), matsya (ikan), madya (alkohol), maithuna (persetubuhan), dan mudra (sikap tangan), bahkan dianggap mampu menimbulkan tenaga-tenaga gaib, apabila dilakukan secara berlebihan. Sehingga ritual yang mereka lakukan adalah dengan melanggar apa yang menurut norma umum sebagai larangan dan melakukannya secara berlebihan (Suharto, 1999: 4-8; Soekmono, 1973: 33-34).

Di dalam banyak tradisi keagamaan penghormatan kepada dewi kesuburan, selalu dekat dengan pesta seks. Pada banyak suku bangsa, dewi kesuburan dilukiskan dalam bentuk seorang wanita atau ibu yang dadanya disorot secara khusus. Dalam buku Strategi Kebudayaan karya van Peursen termuat patung prasejarah dewi Venus dari Willendorf; patung seorang ibu dengan anaknya dari sebuah kuil di Syango (Nigeria) (Peursen, 1988: 83 - 88). Pada masyarakat yang percaya adanya mitosmitos seperti di atas, dikenal adanya nyanyian, doa dan tarian sebagai tradisi ritual untuk menghadirkan kekuatan tokoh-tokoh mitis tersebut. Misalnya, pada awal kebudayaan Cina, lama sebelum Masehi, orang Shaman selalu menciptakan hujan dalam wujud tarian gembira (Sach, 1963: 65 - 67). Fungsi tarian tersebut adalah menciptakan (mengundang) kekuatan yang memiliki daya tumbuh bagi tumbuh-tumbuhan atau datangnya hujan.

Lengger sebagai tarian rakyat yang digunakan dalam upacara-upacara kesuburan juga tidak terhindarkan dari unsur-unsur erotisme. Bagi orang yang tidak memahami kaitan tarian ini dengan latar belakang keyakinan mereka, akan dengan mudah memandang tarian ini sebagai tarian yang tidak senonoh. Padahal sebagai tarian rakyat lengger menjadi perangkat yang dapat membantu para petani mengungkapkan suka cita di hadapan Sang Pencipta yang telah memberi mereka hasil panen yang baik. Gerakan-gerakan tarian lengger yang erotis sekaligus menyimbolkan perkawinan mitis para dewa yang berbuah pada panen yang melimpah.

\section{Pandangan Agama dan Masyarakat Tentang Kesucian Tubuh}

Dilihat dari perspektif kultural, agama merupakan sebuah kekuatan yang mampu menjadikan berbagai pola kebudayaan sebagai sesuatu yang mapan (stable). Di dalam wacana mengenai tubuh, berbagai konsep, nilai dan norma agama dapat menjadi "cetak biru" yang mempunyai fungsi sebagai pakem bagaimana tubuh harus diperlakukan dan bagaimana pola kelakuan orang dengan tubuhnya. Karena dasar acuan nilainya adalah yang transenden atau kosmik, maka nilai-nilai yang ditetapkan oleh agama mempunyai legitimasi yang paling tersebar dan efektif, serta hampir-hampir tidak 
terbantahkan (Berger, 1991: 40-45). Selain sebagai mediator antara manusia dan Tuhan, agama juga memberi batasan yang terang dalam memaknai tubuh dan bagaimana tubuh diperlakukan. Agama dengan tegas menunjuk suatu tindakan dengan menggunakan tubuh disebut tindakan yang moralis atau amoral.

Sumber moral utama dalam Islam adalah Quran dan Hadits. Dari kedua sumber ini kemudian muncul berbagai macam Fiqih mengenai perempuan. Bagaimana Quran, Hadits, dan Fiqih tentang tubuh perempuan ditafsirkan tentu sangat tergantung kepada siapa yang menafsirkannya. Quran secara tegas mengajarkan perlunya menjaga tubuh perempuan dalam pergaulannya dengan lakilaki dengan menutup bagian aurat. Secara garis besar, dalam konteks pembicaraan mengenai aurat perempuan, penafsiran kaum moslem terhadap Quran dan Hadits dapat dikelompokkan menjadi tiga pandangan yang berbeda, yaitu: pertama, pandangan yang menyatakan bahwa seluruh tanpa kecuali adalah aurat; kedua, pandangan yang menyatakan bahwa seluruh tubuh adalah aurat dengan mengecualikan wajah dan telapak tangan; dan ketiga, pandangan yang menyatakan bahwa persoalan aurat dan jilbab merupakan persoalan budaya. Pengelompokan ini dibuat berdasarkan pandangan dan sikap, serta penafsiran mereka terhadap Quran dan Hadits mengenai aurat perempuan. Bisa jadi dalam satu kelompok menurut kategori di atas juga masih ada perbedaan pandangan dan sikap secara lebih detail (Shihab, 2006: 54121).

Pandangan warga masyarakat Banyumas terhadap tubuh dan lengger tidaklah monolitik. Meskipun warga masyarakat Banyumas mayoritas beragama Islam, tetapi pandangan mereka terhadap tubuh tidak seluruhnya di bawah bingkai moralitas Islam terhadap tubuh seperti diuraikan di atas.
Konstruksi negara atas tubuh yang diadopsi dari beberapa kebenaran agama tidak selalu diafirmasi oleh warga negara dalam hal ini adalah masyarakat Banyumas. Masyarakat kadang berada pada posisi resisten terhadap kontol negara tersebut baik secara terangterangan maupun tidak, namun kadang juga tanpa sadar mengafirmasi kontrol negara begitu saja, bahkan ikut menggalakkan kontrol negara tersebut. Pandangan dan sikap warga masyarakat Banyumas terhadap tubuh dan tari lengger dapat di kelompokkan menjadi tiga, yaitu: 1) tari lengger bertentangan dengan ajaran Islam, Kelompok ini mempunyai pandangan bahwa ekploitasi tubuh penari dalam tari lengger bertentangan dengan ajaran Islam tentang perlunya melindungi tubuh perempuan. 2) tari lengger tidak bertentangan dengan ajaran Islam, Kelompok ini memandang bahwa eksploitasi tubuh dalam pentas tari lengger adalah hal yang tidak bertentangan dengan ajaran Islam. Bahwa ada penyimpangan-penyimpangan oleh seniman lengger, hal itu sangat tergantung kepada orang yang menjalaninya. dan 3) kelompok yang memisahkan seni dan agama. Kelompok ini memandang bahwa persoalan tubuh adalah tanggungjawab atau urusan masing-masing pribadi. Agama tidak perlu mengatur urusan ini secara mendetail. Demikian menyangkut seni, agama dan seni sebaiknya tidak dicampur adukkan karena masing-masing mempunyai tatanan sendiri-sendiri.

\section{Pluralitas Pemaknaan Tubuh}

Dari uraian di atas kiranya menjadi jelas bahwa pemaknaan tubuh tidaklah tunggal. Dari sudut pandang agama Islam saja bagaimana tafsir mengenai bagaimana tubuh wanita diperlakukan sekurang-kurangnya ada tiga tafsir. Pluralitas pemaknaan tubuh itu terjadi juga dalam masyarakat yang tinggal pada suatu tempat yang sama seperti terlihat 
dalam masyarakat pandangan desa Gerduren. Uraian di atas memperlihatkan bahwa tubuh merupakan tempat yang paling esensial untuk mengamati penyebaran dan beroperasinya relasi-relasi kekuasaan dalam masyarakat. Tubuh adalah tempat dimana praktik-praktik sosial yang paling lokal (mikro) mempertautkan dirinya dengan sirkulasi kekuasaan yang impersonal dalam skala besar (makro). Lebih jauh tercapai suatu kejelasan mengenai bagaimana suatu tubuh sampai dikotak-kotakan, dikonstitusikan, dan dimanupalasi oleh kekuasaan. Kekuasaan telah mendefinisikan tubuh sebagai sesuatu yang seharusnya natural menjadi bersih atau kotor, suci atau tidak. Kekuasaan pula yang menentukan bahwa tubuh harus dikontrol sedemikian rupa demi perkembangan populasi. Kekuasaan atas tubuh beroperasi secara baik di tengah masyarakat lewat dan dalam anggotaanggota masyarakat itu sendiri. Lebih-lebih ketika kekuasaan itu bergerak atas nama sebuah nilai keagamaan, kekuasaan memperoleh legitimasi yang sangat kuat (Berger, 1991: 42-43).

Namun demikian, tidak selalu kekuasaan yang menggunakan legitimasi kebenaran agama selalu berhasil menembus semua lapisan masyarakat. Resistensi terhadap kekuasaan selalu muncul di tengah masyarakat dalam berbagai bentuknya, lebih-lebih manakala masyarakat menemukan sumber nilai yang dominan dalam hidup mereka. Menurut Foucault resistensi akan selalu ada dalam berbagai bentuk karena resistensi akan selalu ada sejauh kekuasaan ada (Foucault, 1978:95). Resistensi terhadap pendifinisian tubuh oleh agama dan pemerintah muncul dari masyarakat ketika pendefinisian tersebut bertentangan dengan pemaknaan tubuh yang telah hidup di tengah masyarakat dan telah mereka hayati. Masyarakat mempunyai pemaknaan atas tubuhnya berdasarkan praktek ketubuhan masing-masing (Foucault, 1978: 100). Dengan demikian ada pluralitas pemaknaan tubuh. Kiranya menjadi sesuatu yang hampir mustahil mengharapkan adanya konsensus tentang makna tubuh dalam masyarakat yang sangat plural. Selain itu, berbagai konstruksi yang ada telah merefleksikan nilainilai yang bukan hanya dari budaya, melainkan juga berasal dari sub-budaya dan individu-individu yang sarat dengan kepentingan masing-masing. Dengan demikian tubuh menjadi arena pentas bagi negoisasi nilai-nilai dan kepentingankepentingan yang berkembang dalam suatu masyarakat.

\section{Membangun Teologi dari Bawah}

Kata teologi berasal dari kata Yunani theos yang artinya adalah Allah, dan logos yang artinya adalah perkataan, maka teologi berarti perkataan atau ilmu tentang Allah. Tubuh dapat mengatakan atau memperlihatkan atau mengingatkan sesuatu mengenai Allah sebagai penguasa atas tubuh dan kehidupan manusia. Refleksi atas ketubuhan dapat membawa orang sampai kepada pengetahuan tentang Allah. Pengalaman penari lengger berolah tubuh membuat mereka meyakini akan keberadaan Allah sebagai asal mula dari tubuhnya, walaupun mereka tidak berani secara tegas menyebut nama Allah di balik semua pengalamannya tersebut. Pengalaman berolah tubuh memberi mereka keyakinan bahwa ada sesuatu di balik tubuh fisik yang kelihatan ini.

Manusia adalah tubuh sekaligus jiwa. Tanpa jiwa ia bukanlah manusia, melainkan hanya mesin biologis. Tanpa tubuh manusia juga tidak menjadi manusia, karena ia hanya entitas imaterial yang mengambang tanpa basis empiris. Dengan demikian tubuh merupakan aspek penting bagi manusia, baik secara biologis, karena tubuh menunjang 
kehidupan manusia, maupun secara filosofis, yakni sebagai medium untuk menyentuh dunia dan merealisasikan dirinya sendiri. Tentu saja untuk menjadi otentik, orang harus menghargai dan memahami tubuhnya. Tanpa pemahaman tidak akan ada penghargaan, dan tanpa penghargaan tidak akan ada penghayatan. Padahal penghayatan akan tubuhnya sendiri sangatlah berperan di dalam pengenalan diri manusia yang merupakan jalan untuk menuju otentisitas. Penghayatan akan pengalaman ketubuhannya sendiri itulah yang di atas disebut sebagai pengalaman yang subyektif. Dalam pengalaman yang sifatnya subyektif tersebut para penari lengger mengalami dan memahami bahwa mereka tidak berkuasa mutlak atas tubuhnya sendiri, karena mereka harus mengatur dan melatih tubuhnya sesuai dengan tuntutan masyarakat atau pasar (bdk. Synnott, 2007:2). Pengalaman dan pemahaman akan keberadaan tubuhnya yang tidak sepenuhnya berada dalam genggamannya sendiri bagi para penari lengger ini kadang menimbulkan ketegangan yang tidak mudah untuk didamaikan.

Sebagai seorang muslim mereka sadar bahwa apa yang mereka perankan dalam kehidupan tidak sesuai dengan standar ajaran Islam yang berkembang di daerahnya. Meskipun begitu mereka mengalami adanya suatu nilai lain berkaitan dengan keberadaan tubuhnya yang tidak selalu selalu sejalan dengan horison nilai tubuh Islami dalam kacamata Islam pada umumnya. Dengan demikian sebagaimana sudah diuraikan di atas, ada resistensi tertentu dari para penari lengger terhadap nilai-nilai ketubuhan Islam pada umumnya. Resistensi tersebut mereka buat dengan cara merelatifir ajaran Islam. Apa yang menurut umat moslem pada umumnya tidak sesuai dengan ajaran Islam, misalnya soal keberadaan indang, di dalam komunitas lengger dianggap tidak ada masalah bahkan diyakini sesuai dengan ajaran Islam. Mereka juga menciptakan ruang yang terpisah antara ajaran agama dan kesenian (tari lengger). Kenyataan ini membenarkan pendapat bahwa ranah seni mempunyai otonomi relatifnya sendiri. Bagaimana pun seni tari lengger mempunyai komunitas atau masyarakat pendukung. Komunitas pendukung seni lengger ini kurang lebih berada dalam penghayatan dan pemaknaan sama atas praktek ketubuhan tari lengger.

Bagi para penari lengger pengalaman ketubuhan adalah pengalaman yang mendasar. Pengalaman ketubuhan mereka menjadi pewahyuan kebenaran yang bersifat subyektif tetapi mempunyai kekuatan yang berakar dalam kedalaman hidup mereka. Kebenaran yang diwahyukan oleh pengalaman tersebut bisa jadi akan terkoreksi oleh pengalaman yang lain, namun sejauh tidak ada pengalaman baru yang lebih mendasar maka pewahyuan kebenaran tersebut akan kokoh, apalagi kalau pengalaman-pengalaman berikutnya mengafirmasi atau membenarkan pengalaman sebelumnya. Pengalaman yang bersifat subyektif bukan berarti bahwa pengalaman tersebut tidak dapat dipertanggungjawabkan kebenarannya karena pengalaman subyektif berkaitan dengan apa yang disebut Merleau-Ponty sebagai persepsi (Carman, 2008: 78). Pengalaman tersebut dianggap subyektif karena dialami oleh manusia secara pribadi-pribadi, dan tidak sama dengan apa yang secara umum diyakini sebagai kebenaran.

Kalau pengalaman ketubuhan menjadi pengalaman dasar yang dapat mengantar orang sampai kepada pengalaman akan yang transenden atau biasa disebut Allah, maka teologi tubuh sebagai sebuah refleksi iman sudah seharusnya bertolak dari pengalaman ketubuhan bukan pertama-tama bertolak dari suatu rumusan-rumusan doktrin. Pengalaman ketubuhan -pengalaman bergelut dengan 
tubuhnya sendiri- bagi penari lengger telah menjadi pewahyuan bagi mereka bahwa yang transenden dapat dijumpai dalam tubuhnya. Bagi mereka yang transenden atau Allah bukan menjadi sesuatu yang asing dan jauh dari jangkauan mereka karena yang transenden telah mewahyukan diri-Nya melalui tubuh mereka sendiri. Mereka dapat belajar mengenai yang transenden dan kehidupan yang berasal dari-Nya melalui tubuh yang mereka hidupi dari waktu ke waktu. Penyertaan yang transenden mereka rasakan dalam berbagai cara yang mereka alami dalam pengalaman pengalaman ketubuhan mereka. Model refleksi ketubuhan yang juga merupakan refleksi teologis para penari lengger ini kiranya dapat menjadi suatu model yang dapat ditawarkan kepada agama-agama dalam membuat refleksi atau berteologi mengenai tubuh.

Model refleksi atas pengalaman ketubuhan penari lengger ini sebenarnya juga telah menginspirasikan beberapa kelompok. Mereka yakin bahwa di balik warna, bentuk, siklus biologis, bau dan sampahnya, tubuh menyimpan inspirasi-inspirasi untuk sampai kepada Yang Ilahi (transenden). Tubuh memberikan inspirasi yang sangat kaya karena di dalam tubuh terkandung berbagai dimensi pengalaman, termasuk di dalamnya adalah dimensi transendental. Oleh karena itu, pengalaman kebertubuhan adalah sumber inspirasi yang multi dimensional. Bagi para teolog perempuan "menstruasi mengingatkan kita akan siklus-siklus alam yang diciptakan oleh Tuhan dan proses melahirkan sebagai simbol partisipasi dalam kreativitas yang ilahi" (Meliana, 2006: 24). Dengan demikian tubuh dan seksualitasnya bukan hanya menjadi beban karena anggapan akan kekotorannya, tetapi dapat menjadi sesuatu yang bermakna transenden. Seksualitas adalah bagian tak terpisahkan dari tubuh. Kita semua adalah makluk seksual. Seksualitas adalah kapasitas manusiawi untuk memasuki pengalaman cinta dan pemberian diri kepada orang lain. Tuhan menciptakan tubuh seksual ini bagi kita. Orang tidak dapat tidak adalah seksual. Karena kita adalah makluk bertubuh, maka kita berelasi dengan Tuhan memakai dan melalui tubuh kita. Tubuh yang telentang, berlutut, bersujud, bersila bukan hanya persiapan untuk doa. Tubuh-tubuh sendiri adalah doa, doa dengan tubuh (de Mello, 1979: 39).

\section{D.SIMPULAN}

Keberadaan tari lengger bagaimanapun ada dalam negoisasi dengan macam-macam kepentingan yang berinteraksi di tengah masyarakat, yaitu kepentingan agama, ekonomi (pasar), politik, dan budaya yang bermain di tengah masyarakat desa Gerduren. Ada pergeseran-pergeseran di tengah masyarakat yang menuntut respon yang berbeda dari mereka yang hidup di dalamnya. Di sini dapat dilihat bahwa makna dari sesuatu, sebagaimana diuraikan di atas, merupakan bentukan yang sarat dengan nilai yang mengakomodasikan kepentingan para pihak yang terlibat. Dalam konteks pergeseran semacam ini simbol kebudayaan akhirnya bukan lagi sebagai pengarah suatu masyarakat yang memiliki daya paksa, tetapi menjadi alat politik bagi perjuangan kepentingan para pihak, baik individual, kelompok, maupun institusi. Simbol-simbol agama tidak hanya menjadi penunjuk arah dari suatu praktik yang berhubungan dengan religiusitas, tetapi juga bagi sebagian orang, kelompok atau institusi, menjadi alat bagi legitimasi atas keberadaan dan kepentingan (bdk. Abdullah, 2006:9).

Di sinilah pentingnya mengangkat pengalaman personal dalam studi tentang tubuh lengger. Di atas diuraikan bahwa para penari lengger menemukan yang ilahi dalam 
olah tubunya. Karena tubuh merupakan ciptaan Allah, maka jejak Sang Pencipta juga dapat ditemukan di dalam tubuh. Hal ini selanjutnya menjadi tantangan bagi para seniman lengger, bagaimana olah tubuhnya dapat membantu orang lain sampai kepada Allah. Para penari lengger perlu mentranformasi diri supaya olah tubuhnya mampu membuat orang semakin mengenali tubuhnya dengan baik, dan mampu mengenali Allah lewat tubuhnya tersebut, dan bukan jatuh pada erotisme belaka yang justru membuat orang kehilangan pengenalan akan Allah dalam tubuhnya sendiri. Selain upaya pemaknaan dan wacana baru yang perlu dibangun terus-menerus, juga harus ada usaha untuk membaharui gerak tari lengger, sehingga gerak tari lengger sesuai dengan pemaknaan atau wacana baru yang diperjuangkan.

Cara berolah tubuh atau gerak tari yang sesuai dengan wacana ketubuhan yang baru tentu akan membantu masyarakat untuk berolah tubuh, dan membuat penafsiran yang tepat sehingga orang dapat menikmati keindahan gerak tubuh tanpa adanya rasa takut untuk terjebak dalam dosa. Untuk itu, sangat diperlukan penafsiran ajaran agama berkaitan dengan persoalan ketubuhan secara tepat, sesuai dengan kaidah tafsir yang benar, agar ajaran agama dapat kontektual, artinya mampu menjawab permasalahan dan tantangan jaman yang ada. Selain itu, penafsiran yang tepat juga akan membantu umat beragama untuk menerapkan ajaran agama dalam hidup di tengah masyarakat secara nyata, sehingga orang tidak hanya beragama secara formalitas. Barangkali dari kalangan seniman lengger tidak akan pernah lahir penafsir teks keagamaan yang mampu membuat tafsir yang benar berkaitan dengan pemaknaan tubuh dalam Islam dalam konteks budaya (seni tari lengger).
Di sinilah peran dari tokoh keagamaan yang kreatif dan mampu memahami budaya, khususnya tarian rakyat sejenis lengger diperlukan. Diperlukan usaha yang lebih untuk menemukan sintesis antara ajaran agama dan nilai-nilai budaya tanpa mengurbankan salah satunya. Barangkali inkulturasi adalah metode yang dapat ditawarkan. Inkulturasi harus disertai kesadaran bahwa dalam kebudayaan benihbenih "Sabda Allah" sudah hadir secara tersamar, sehingga dengan demikian ada usaha untuk menghargai setiap bentuk kebudayaan sebagai karya manusia yang tentunya Allah pun berkarya di sana. Perlu diperhatikan bahwa inkulturasi tidak sekedar pada bentuk-bentuk luar yang tidak menyentuh pengalaman batin. Untuk itu, harus ada upaya untuk menghargai pengalaman spiritual atau pengalaman religiusitas para penari lengger bahwa mereka lewat caranya telah menemukan kehadiran yang ilahi secara imanen. Tentu dibutuhkan kerendahan hati kaum agawan untuk belajar menghargai adanya kebenaran di luar agamanya, belajar menerima apa yang baik, dan kerelaan untuk meninggalkan kemapanannya sebagai satusatunya penguasa wacana kebenaran.

\section{DAFTAR PUSTAKA}

Abdullah, Irwan, 2006, Konstruksi dan Reproduksi Kebudayaan. Yogyakarta, Pustaka Pelajar.

Berger, Peter L., 1990. The Sacred Canopy. New York, Anchor Books.

Carman Taylor, 2008. Merleau-Ponty, Oxon, Routledge.

De Mello, Anthony, SJ., 1979. Sadhana. Yogyakarta. Kanisius.

Foucault, Michael, 1978. History of Sexuality. New York: Vintage Book. 
1979. Power, Truth, Strategy. Sydney, Feral Publications.

Koentjaraningrat, 1994. Kebudayaan Jawa. Jakarta, Balai Pustaka.

Langer, Susane K., 1953. Feeling and Form. New York, Charles Scribner's Sons.

Mangunwijaya, Pr. Y.B., 1975. Ragawidya. Yogyakarta, Kanisius.

Melliana S, Annastasi, 2006. Menjelajah Tubuh Perempuan dan Mitos Kecantikan. Yokyakarta, LKIS.

Mulia, Musdah, 2007. Islam dan Inspirasi Kesetaraan Gender. Yogyakarta, Kibar Press.

Peursen, C.A. van, Prof, Dr., 1976. Strategi Kebudayaan. Yogyakarta, Kanisius.

Sach, Curt, 1963. World History of The Dance. New York. Norton and Company.

Shihab, M. Quraish, 2006. Jilbab, Pakaian Wanita Muslimah, Jakarta, Lentera Hati.
Soekmono, R., 1973. Pengantar Sejarah Kebudayaan Indonesia, Yogyakarta, Kanisius.

Suharto, Ben, 1999. Tayub, Pertunjukan dan Ritus Kesuburan. Bandung. Masyarakat Seni Pertunjukan Indonesia.

Sunaryadi, 2000. Lengger: Tradisi dan Transformasi. Yogyakarta. Yayasan Untuk Indonesia.

Suraji, 2004. Religiusitas Lengger Desa Gerduren. Yogyakarta, Universitas Gadjah Mada.

Synnott, Anthony, 1993. The Body Social: Symbolism, Self and Society. London and New York, Routledge.

Tohari, Ahmad, 1995. Ronggeng Dukuh Paruk. Jakarta 